\title{
Synthesis of Some Vanillin Derivatives and their Use as an Optical Sensor for the Detection of Volatile Organic Compounds
}

\author{
Abdullah M. Asiri, Gameel A. Baghaffar, \\ Ali M. Al-Harby and Mohie Aldien M. Zayed \\ Chemistry Department, Faculty of Science, \\ King Abdulaziz University, Jeddah, Saudi Arabia
}

\begin{abstract}
Six new dyes derived from vanillin and active methylene have been prepared and characterized using H-NMR, FT-IR spectral data. These dyes were tested for use as sensors for volatile organic compounds (VOCs namely Triethyl amine and diethyl amine). The electronic spectra of these dyes was examined and gave color depending on the acceptor groups. The compounds were tested to sense organic amines such as diethyl amine and triethyl amine, all the compounds tested gave color change from less color to deep color which can be seen by naked eye, rendering these materials to be easy, inexpensive sensor for volatile organic compounds which are basic in nature.
\end{abstract}

Keywords: Vanillin, Sensors, Volatile organic compounds (VOC), sensing amins.

\section{Introduction}

In recent years, the solid state gas sensors demand for safety control requirements, environmental monitoring and food quality control has expanded enormously. In particular the detection of volatile organic compounds in low concentration, has become of interest, because they are widely used as ingredients house-hold products. These compounds vaporize at normal room temperature, sometimes causing adverse health effects. Moreover, foods emit mainly low molecular weight alcohols and esters, but also amines and aldehydes are present. 
To this purpose the sensing elements necessary to monitor specific gases or VOCs must demonstrate high selectivity feature. In the cases in which the sensing element not shows the required selectivity, a development of an array configuration becomes indispensable. Consequently, a great interest on searching the solid state gas sensor with high sensitivity, stability and wide selectivity spectrum has been developed. In array configuration each sensing element must demonstrate a broad selectivity range towards various kinds of volatile organic compounds. But there is a research competition between the possible realization of large number of sensors element disposed in array configuration or the tentative to modify the sensing technique in order to increase the selectivity of a specific sensitive material. In the first case the increasing of the number of sensing elements leads to increase the dimension of the system and the complexity of the sensing equipment. The second approach consists in the modification of the sensing technique, by minimizing the use of the sensing material. Different transduction techniques are used for gases or VOCs detection such as electrical conductivity ${ }^{[1,2]}$ mass transduction ${ }^{[3,4]}$, surface acoustic wave ${ }^{[5]}$ optical variation in the physical properties of the sensing elements ${ }^{[6]}$. In the last case optical detection of gases are based on the change in the optical properties of thin films (e.g. refractive index, extinction coefficient, thickness, absorption, ... etc.) due to the interaction of the sensing layer with the molecules of the gas.

In this investigation we will consider some VOCs which are of interest in food analysis. In particular those compounds with a wellknown toxicity such as amines. Alcohols are also present in flower and fragrances related to many food products and involved in fats deterioration processes.

Moreover, these chemicals were possible to be prepared in the form of thin films using different chemical deposition techniques like casting, spin coating, Langmuir-Blodgett, or physical technique like thermal evaporation $^{\text {[7-20]. }}$. 


\section{Experimental}

Melting points were recorded on a Thomas-Hoover capillary melting apparatus without correction. IR spectra were taken as $\mathrm{KBr}$ disks on a Nicolet Magna 520 FTIR spectrometer. NMR spectra were obtained with a Bruker DPX $400(400 \mathrm{MHz})$ spectrometer using CDCl3 solutions. UVvisible spectra were recorded on a Shimadzu 1650 PC spectrometer for solutions.

\section{Materials}

Vanillin, malononitrile, ethyl cyanoacetate, barbituric acid, thieobarbituric acid, indan1, 3-one, N,N-diethylthieobarbituric acid, and all other solvents and reagents were purchased from Across chemicals and used without any further purification.

\section{General Procedure}

A solution of vanillin $(1.0 \mathrm{~g}, 6.58 \mathrm{mmol})$ and an equivalent amount of the active methylene compounds $(6.58 \mathrm{mmol})$ in ethanol $(10 \mathrm{~mL})$ was wormed before addition of diethylamine ( 2 drops). After the addition was completed the reaction mixture was refluxed for 1-2 hours, cooled to room temperature and the precipitate product was collected by filtration and dried. The physical and spectral data of the synthesized compounds are given in Tables 1, 2 and 3.

Table 1. Physical data for vanillin dyes 1-6.

\begin{tabular}{|c|c|c|l|}
\hline Dye no. & m.p. $/{ }^{\circ} \mathbf{C}$ & \% of yield & \multicolumn{1}{|c|}{ MF } \\
\hline 1 & $120^{\circ} \mathrm{C}$ & $16.73 \%$ & $\mathrm{C}_{11} \mathrm{H}_{8} \mathrm{~N}_{2} \mathrm{O}_{2}$ \\
\hline 2 & $50^{\circ} \mathrm{C}$ & $84.92 \%$ & $\mathrm{C}_{13} \mathrm{H}_{13} \mathrm{NO}_{4}$ \\
\hline 3 & $270^{\circ} \mathrm{C}$ & $87.20 \%$ & $\mathrm{C}_{12} \mathrm{H}_{10} \mathrm{~N}_{2} \mathrm{O}_{5}$ \\
\hline 4 & $220^{\circ} \mathrm{C}$ & $56.34 \%$ & $\mathrm{C}_{12} \mathrm{H}_{10} \mathrm{~N}_{2} \mathrm{O}_{4} \mathrm{~S}$ \\
\hline 5 & $120^{\circ} \mathrm{C}$ & $11.83 \%$ & $\mathrm{C}_{16} \mathrm{H}_{18} \mathrm{~N}_{2} \mathrm{O}_{4} \mathrm{~S}$ \\
\hline 6 & $185^{\circ} \mathrm{C}$ & $60.26 \%$ & $\mathrm{C}_{17} \mathrm{H}_{12} \mathrm{O}_{4}$ \\
\hline
\end{tabular}


Table 2. H-NMR data of vanilins 1-6.

\begin{tabular}{|c|c|}
\hline Dye no. & $\delta(\mathrm{ppm}) / \mathrm{CDCl}_{3}$ as solvent \\
\hline 1 & $\begin{array}{l}3.92\left(3 \mathrm{H}, \mathrm{s}, \mathrm{CH}_{3} \mathrm{O}\right), 6.97-7.00(1 \mathrm{H}, \mathrm{d}), 7.33-7.35(1 \mathrm{H}, \mathrm{d}), 7.66-7.72(1 \mathrm{H}, \mathrm{d}), \mathrm{s} \\
8.01(1 \mathrm{H}, \mathrm{s} \text {, Olefinic Proton })\end{array}$ \\
\hline 2 & $\begin{array}{l}\left.\text { 1.23-1.39 (3H,t, } \mathrm{CH}_{3}\right), 3.72\left(2 \mathrm{H}, \mathrm{q}, \mathrm{CH}_{2} \mathrm{O}\right), 4.01\left(3 \mathrm{H}, \mathrm{s}, \mathrm{CH}_{3} \mathrm{O}\right), 5.63(1 \mathrm{H}, \mathrm{s}, \\
\mathrm{OH}), 6.58-6.63(1 \mathrm{H}, \mathrm{d}), 6.846 .86(1 \mathrm{H}, \mathrm{d}), 6.99-7.02(1 \mathrm{H}, \mathrm{d}), 8.46(1 \mathrm{H}, \mathrm{s} \text {, } \\
\text { Olefinic Proton). }\end{array}$ \\
\hline 3 & $\begin{array}{l}3.88\left(3 \mathrm{H}, \mathrm{s}, \mathrm{CH}_{3} \mathrm{O}\right), 5.2(1 \mathrm{H}, \mathrm{s}, \mathrm{OH}), 7.03(1 \mathrm{H}, \mathrm{d}), 7.26(1 \mathrm{H}, \mathrm{d}), 7.31(1 \mathrm{H}, \mathrm{d}) \text {, } \\
7.96(1 \mathrm{H}, \mathrm{s} \text {, Olefinic Proton }) .\end{array}$ \\
\hline 4 & $\begin{array}{l}3.98(3 \mathrm{H}, \mathrm{s}), 4.40(1 \mathrm{H}, \mathrm{s}, \mathrm{OH}), \mathrm{d} 6.99-7.01(1 \mathrm{H}, \mathrm{d}), 7.385-7.388(1 \mathrm{H}, \mathrm{d}), \\
7.852-7.855(1 \mathrm{H}, \mathrm{d}), 8.14(1 \mathrm{H}, \mathrm{s}, \text { Olefinic Proton }) .\end{array}$ \\
\hline 5 & $\begin{array}{l}1.25\left(6 \mathrm{H}, \mathrm{t}, \mathrm{CH}_{3} \mathrm{CH}_{2}\right), \mathrm{s} 3.29\left(4 \mathrm{H}, \mathrm{q}, \mathrm{CH}_{3} \mathrm{CH}_{2}-\right), 3.94\left(3 \mathrm{H}, \mathrm{s}, \mathrm{CH}_{3} \mathrm{O}\right), \mathrm{s} 5.94 \\
(1 \mathrm{H}, \mathrm{s}, \mathrm{OH}), 6.63(\mathrm{~d}, 1 \mathrm{H}), \mathrm{s} 7.74(\mathrm{~d}, 1 \mathrm{H}), 7.99(\mathrm{~d}, 1 \mathrm{H}), 8.42(1 \mathrm{H}, \mathrm{s} \text {, Olefinic } \\
\text { Proton). }\end{array}$ \\
\hline 6 & $\begin{array}{l}3.93\left(3 \mathrm{H}, \mathrm{s}, \mathrm{CH}_{3} \mathrm{O}\right), 5.21(1 \mathrm{H}, \mathrm{s}, \mathrm{OH}), 6.97-6.99(1 \mathrm{H}, \mathrm{s}), 7.64-7.68(1 \mathrm{H}, \mathrm{s}) \\
7.77(1 \mathrm{H}, \mathrm{s}), 7.81-7.83(2 \mathrm{H}, \mathrm{d}), 7.93-7.99(2 \mathrm{H}, \mathrm{d}), 8.84(1 \mathrm{H}, \mathrm{s} \text {, Olefinic } \\
\text { Proton). }\end{array}$ \\
\hline
\end{tabular}

Table 3. IR Spectral data of vanillin dyes 1-6.

\begin{tabular}{|c|l|}
\hline Dye no. & \multicolumn{1}{|c|}{ v/cm-1 } \\
\hline 1 & $3345.5,2212,2226,1571,1193,1028.6,1193$ \\
\hline 2 & $3447,2232,1621.9,1210.1,1035.7,1108.7,1210.1$ \\
\hline 3 & $3277.9,1666.4,1746.3,1178.6,1010.4,1178.6$ \\
\hline 4 & $3373.2,3562.2,1581.8,1024.7,1219.4$ \\
\hline 5 & $3355,1631.3,1203.1,1032.8,1133.6 \& 1203.1$ \\
\hline 6 & $3451.9,3553.3,1667,1570.6,1152.1,1198.3,1664.4,1708.8,1020.3,1092.9$, \\
\hline
\end{tabular}

\section{Results and Discussion}

\section{Synthesis of Dyes 1-6}

Dyes 1-6 were prepared using knovenagel condensation as shown in Scheme 1. The dyes 1-6 were characterized using different spectroscopic techniques such as $\mathrm{H}^{1}$-NMR, FT-IR. The $\mathrm{H}^{1}$-NMR data are summarized in Table 2. the most significant proton signal of these dyes is the signal of olifinic protons which centered in the range of 7.96-8.84 ppm. The large 
chemical shifts of this signals depends on the strength of the electron withdrawing groups, and also depends on the rigidity of such electron withdrawing moieties which shield the olifinic protons in different ratio. Table 3 summarizes the FT-IR data of dyes 1-6. One significant absorption which common for all dyes is the stretching absorption bands for $\mathrm{OH}$ which located in the region of $3278-3452 \mathrm{~cm}^{-1}$. Other bands are cyano stretching at $2232 \mathrm{~cm}^{-1}$ for dye 2 .
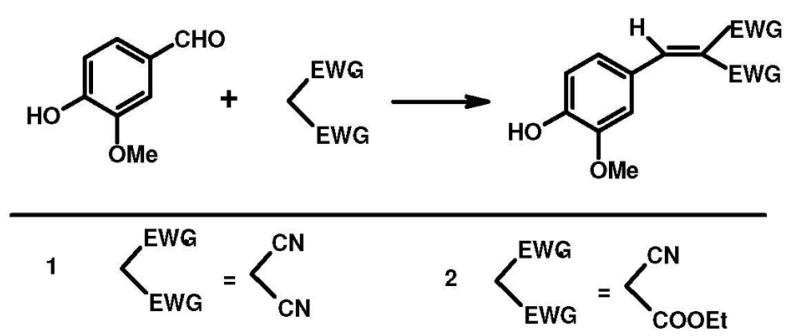

3

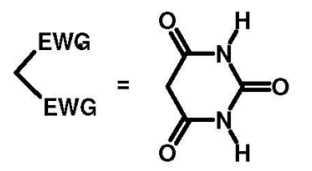

5

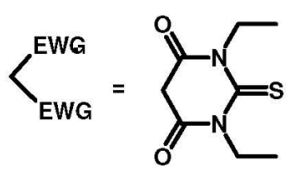

4

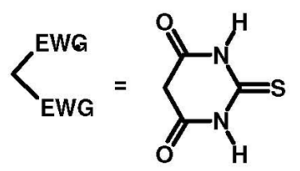

6<smiles>[Mg][Mg]</smiles><smiles>O=C1CC(=O)c2ccccc21</smiles>

Scheme 1

\section{Assessment of Sensing Properties of the Synthesized Dyes 1-6 against Volatile Organic Amines}

\section{Sensing of Diethyl Amine (DEA) and Triethyl Amine (TEA)}

The importance of this paper comes from the fact that, sensors are sophisticated technology and expensive to acquire. This paper aims to present a simple sensor system which can be effective in simple way and can be judged visually by naked eye in the places where we need to sense some volatile organic materials.

The simple sensing mechanism is based on the fact that, the hydroxyl group of the vaniline is acidic and it can react with bases such as organic amines or any material with basic nature, to produce oxonium 
anion (Scheme 2), which is coloured. The colour of the oxonium ion depends on the nature of the acceptor present. Figures 1-5 represent the sensing of diethyl amins and Fig. 6 represents sensing of triethyl amine in ethanol at various amounts of the amine.

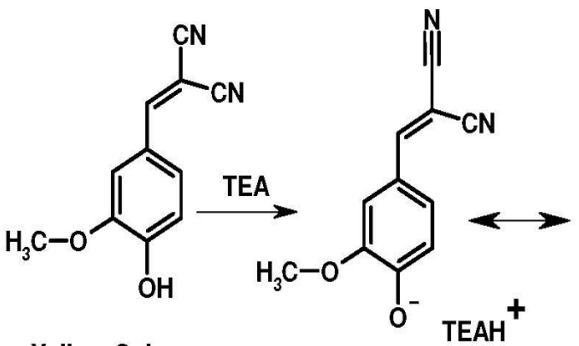

Yellow Colour

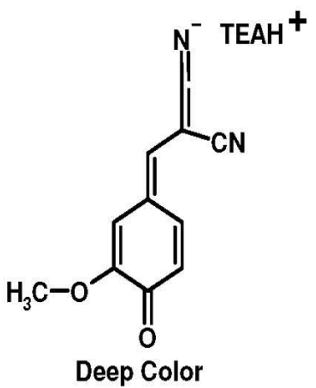

Deep Color

Scheme 2

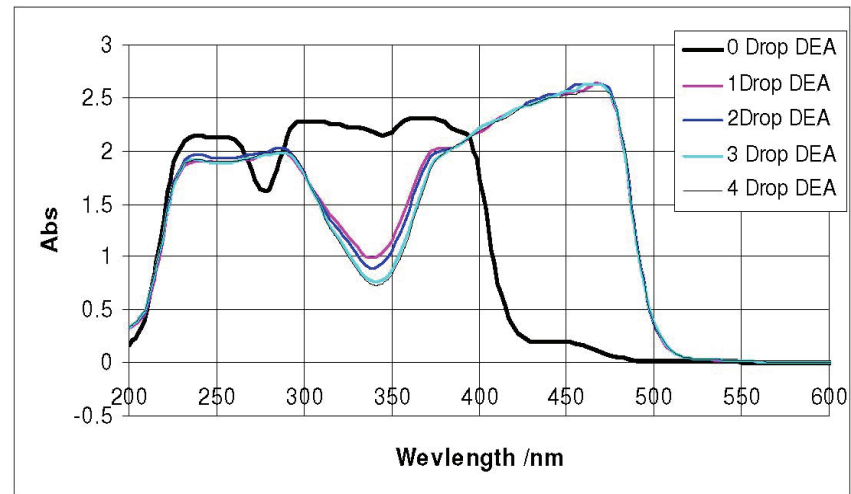

Fig. 1. UV - visible spectra of vanilin 1 in ethanol at various amounts of DEA.

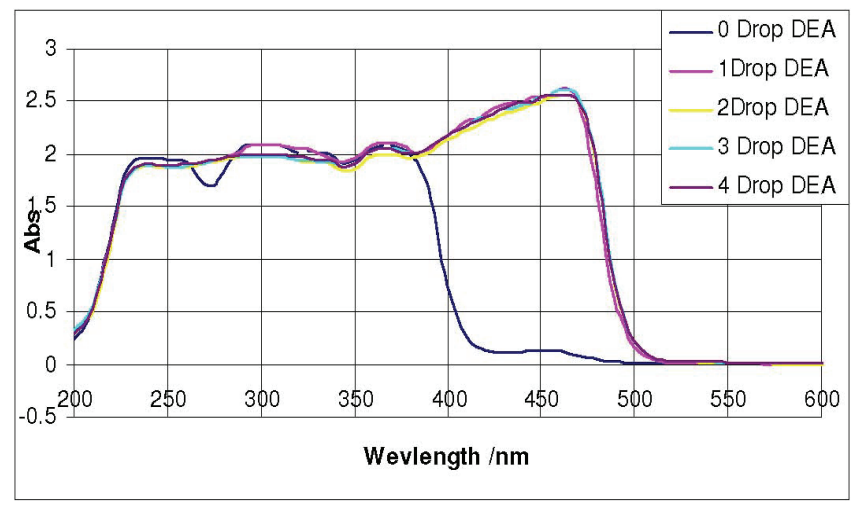

Fig. 2. UV - visible spectra of vanilin 2 in vthanol at various amount of DEA. 


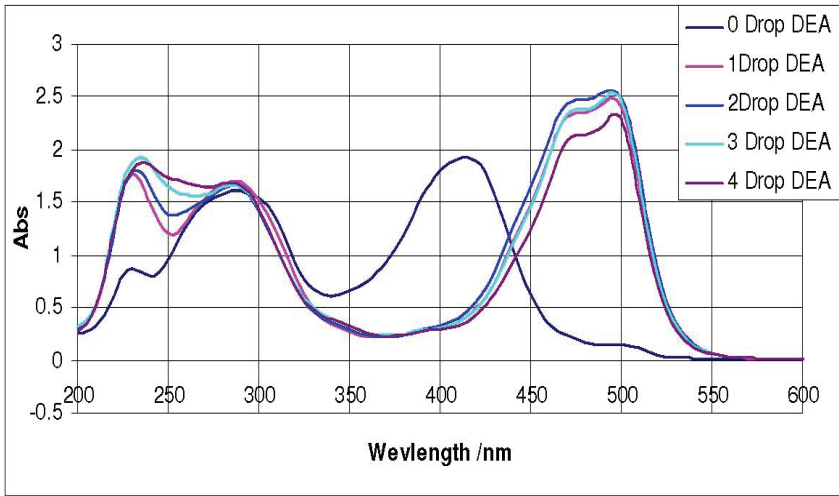

Fig. 3. UV - visible spectra of vanilin 3 in ethanol at various amount of DEA .

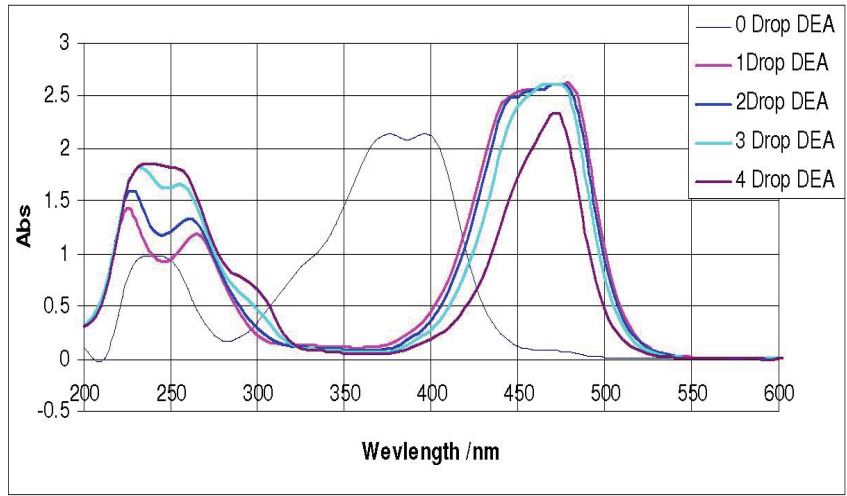

Fig. 4. UV - visible spectra of vanilin 4 in ethanol at various amount of DEA.

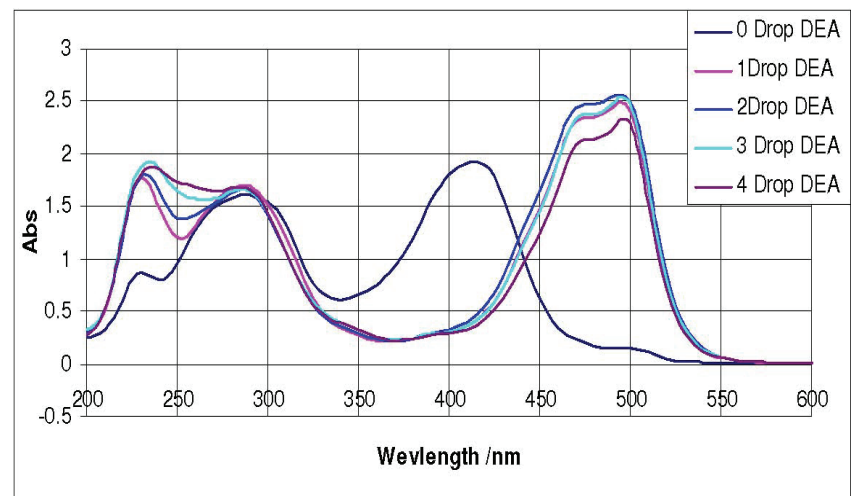

Fig. 5. UV - visible spectra of vanilin 5 in ethanol at various amount of DEA. 


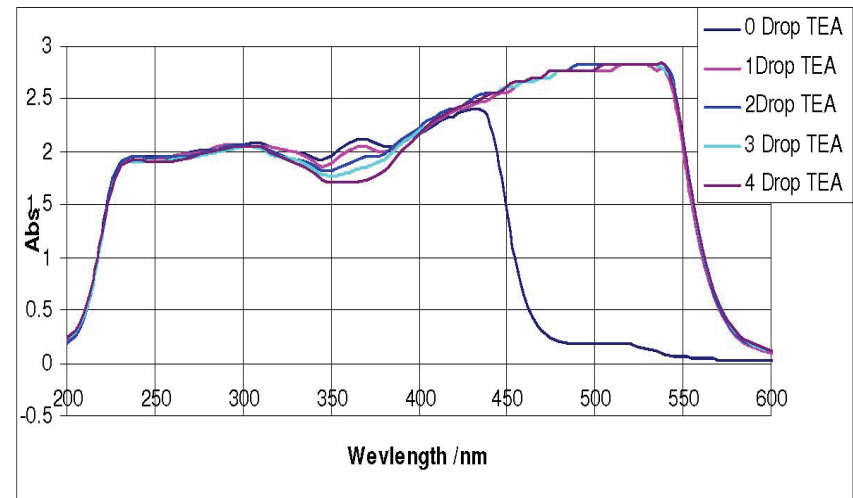

Fig. 6. UV - visible spectra of vanilin 6 in ethanol at various amount of TEA.

\section{Construction of Simple Sensor Device}

A simple sensor device based on this approach was made by casting the vaniline dye on a substrate such as glass or paper, after drying the casting solvent, the device is ready for use. Exposing the device to the vapor of the Amines gave a colour change from yellow to deep red in the case of dye $\mathbf{1}$. The other dyes showed the same color change and the colour formed depends on the dye.

\section{Conclusion}

The Vanillin dyes 1-6 prepared in this paper are potential candidates to be used as sensors for amines and some other materials with basic nature.

\section{References}

[1] Di Natale, C., Macagnano, A., Nardis, S., Paolesse, R., Falconi, C., Proietti, P. Siciliano, Rella, R., Taurino, A. and D'Amico, A., Sens. Actuators, B 78: 303-309 (2001).

[2] Rella, R., Siciliano, P., Toscano, G., Valli, L., Schenetti, L., Mucci, A. and Iarossi, D., Sens. Actuators, B 59: 125 (1999).

[3] Brunink, J., Di Natale, C., Bulgaro, F., Davide, F., D’Amico, A., Paolesse, R., Boschi, T., Faccio, M. and Ferri, G., Meas. Sci. Technol., 7:1103-1114 (1996).

[4] Ni, R., Zhang, X.B., Liu, W., Shen, G.L. and Yu, R.Q., Sens. Actuators, B88: 198-204 (2003).

[5] Cheeke, J.D.N. and Wang, Z., Sens. Actuators, B 59: 146 (1999).

[6] Rella, R., Siciliano, P., Valli, L., Spaeth, K. and Gauglitz, G., Sens. Actuators, B 48: 328 (1998).

[7] Rella, R., Spadavecchia, J., Ciccarella, G., Siciliano, P., Vasapollo, G. and Valli, L., Sens. Actuators, B 89: 86 (2003).

[8] Ho, K.C. and Tsou, Y.H., Sens. Actuators, B 77: 253 (2001). 
[9] Karabork, M. and Serin, S., Synth. React. Inorg. Metal-Organic Chem., 32(9): 1635-1647 (2002).

[10] Spadavecchia, J., Ciccarella, G., Buccolieri, A., Vasapollo, G. and Rella, R., Porphyrins Phthalocyanines, 7: 572 (2003).

[11] Torres, T.J., Porphirins Phthalocyanines, 4: 325-330 (2000).

[12] Langmuir, I. and Schaefer, V.J., J. Am. Chem. Soc., 57: 1007 (1938).

[14] Ulman, A., An Introduction to Ultrathin Organic Films From Langmuir-Blodgett to SelfAssembly, Academic Press, Inc., San Diego (1991).

[13] Kato, T., Jpn. J. Appl. Phys., Part 2, 27: 2128 (1988).

[15] Ouyang, J. and Lever, A.B.P., J. Phys. Chem., 95: 5272 (1991).

[16] Pasimeni, L., Meneghetti, M., Rella, R., Valli, L., Granito, C. and Troisi, L., Thin Solid Films, 58: 265 (1995).

[17] Capone, S., Rella, R., Siciliano, P., Vasanelli, L., Valli, L. and Troisi, L., Thin Solid Films, 465:327-329 (1998).

[18] Rella, R., Spadavecchia, J., Ciccarella, G., Siciliano, P., Vasapollo, G. and Valli, L., Sens. Actuators, B89: 86-91 (2003).

[19] Di Natale, C., Davide, F. and D'Amico, A., Sens. Actuators, B 23: 111-118 (1995).

[20] Hierlemann, A., Schweizer-Berberich, M., Weimar, U., Kraus, G., Pfau, A. and Göpel, W., Sensors Update, VCH, Weinheim, 5: 121-176 (1991). 
تحضير بعض مشتقات الفانيلين و استخدامها كمحسسات ضوئية للكثف عن المركبات العضوية المتطايرة

عبدالله عسيري، وجميل باغفار، وعلي الحربي، ومحي الدين زايد

قسم الكبياء، كلية العلوم، جامعة الدلك عبدالعزيز - جدة المملكة العربية السعودية

المستخلص. ثم تصنيع بعض مشتقات الفانيلين كمحسسات جديــدة

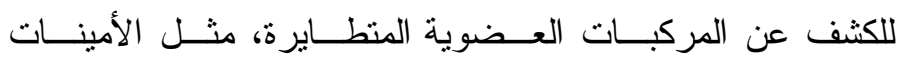

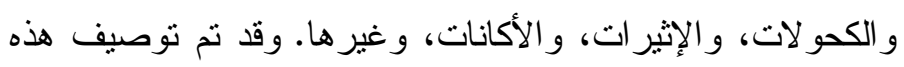

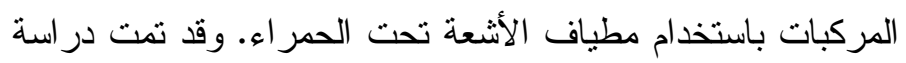

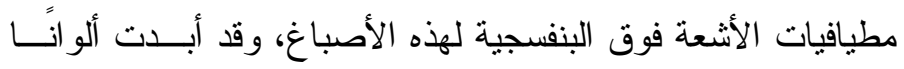

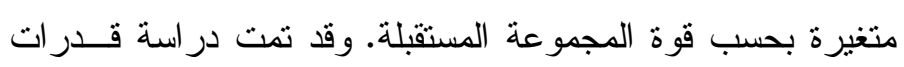
المركبات على تحسس المركبات العضوية، مثل ثنائي إثيل الأمين،

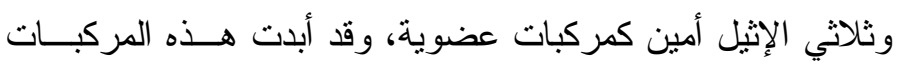

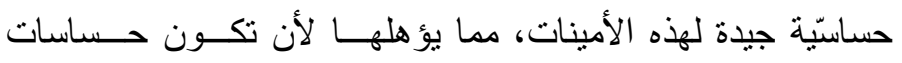
رخيصة وسهلة للمركبات العضوية ذات الخو اص القاعدية. 